\title{
Study on preparation procedure and standardization of recipe for tikhur Barfi
}

\author{
- DeO Shankar*, N. ShuKLA ${ }^{1}$, J.L. NAG ${ }^{2}$ and M.K. SAHU ${ }^{3}$ \\ Shaheed Gundadhoor College of Agriculture and Research Station (I.G.K.V.), Jagdalpur, BASTAR (C.G.) INDIA \\ (Email: deo1975ram@gmail.com) \\ ${ }^{1}$ Department of Horticulture, College of Agriculture, Indira Gandhi Krishi Vishwavidyalaya, RAIPUR (C.G.) INDIA \\ ${ }^{2}$ Department of Horticulture, College of Agriculture (I.G.K.V.), KANKER (C.G.) INDIA \\ ${ }^{3}$ Krishi Vigyan Kendra (I.G.K.V.), NARAYANPUR (C.G.) INDIA
}

*Author for Correspondence

Research chronicle : Received : 21.08.2014; Revised : 03.11.2014; Accepted : 20.11.2014

\begin{abstract}
SUMMARY :
An investigation was conducted at Indira Gandhi Krishi Vishwavidyalaya, Shaheed Gundadhoor College of Agriculture and Research Station, Kumhrawand, Jagdalpur, Bastar, Chhattisgarh in Horticultural laboratory under AICRP on Tuber Crops and RKVY\#16. The experiment was undertaken during January, 2010 and January, 2011. The experiment was laid out in Completely Randomized Design in which 16 treatments tested in three replications for identification of best recipe for preparation of tikhur Barfi. High rhizome and starch yielded genotype IGSJT-10-2 of tikhur was selected as an experimental material and starch of above genotype used for preparation of tikhur Barfi. Tikhur Barfi was prepared in Horticulture laboratory for evaluation of best recipe among 16 different treatments. The different recipe combination of tikhur starch, sugar and water in 16 treatments were taken to standardize the recipe. The results clearly indicated that the highest score was also awarded to recipe $T_{16}$ for sweetness. Highest score of 9.0 was awarded by panel of 11 judges after organoleptic taste of tikur Barfi to treatment $\mathrm{T}_{8}=1: 1.5: 2.5$ (Tikhur starch: Sugar: Water). The hedonic scale rating of treatment $\mathrm{T}_{8}$ was awarded liked extremely (LE) and liked slightly (LS) after 10 days storage by Judges. The highest score was awarded to treatment $\mathrm{T}_{8}$ for its appearance, flavour, fibrousness sweetness, texture and moisture content and similarly $\mathrm{T}_{8}$ also recorded. Highest score was also awarded to treatment $\mathrm{T}_{8}$ for overall acceptability just after preparation and after 10 days storage by panel of judges. On the basis of above findings it can be concluded that the treatment or recipe combination $\mathrm{T}_{8}=1: 1.5: 2.5$ (Tikhur starch: Sugar: Water) was best for the preparation of tikhur Barfi. On the other hands tikhur Barfi prepared through the recipe 1:1.5 2.5 (Tikhur starch: Sugar: Water) had a pleasant flavour, texture, taste moisture, texture appearance and over all acceptability.
\end{abstract}

KEY WORDS : Tikhur, Curcuma angustifolia Roxb., Tikhur barfi, Organoleptic score, Hedonic scale rating, Recipe

How to cite this paper : Shankar, Deo, Shukla, N., Nag, J.L. and Sahu, M.K. (2014). Study on preparation procedure and standardization of recipe for tikhur Barfi. Internat. J. Proc. \& Post Harvest Technol., 5 (2) : 156-164. 